\title{
Irinotecan induces steroid and xenobiotic receptor (SXR) signaling to detoxification pathway in colon cancer cells
}

\author{
Agnes Basseville ${ }^{1,2}$, Laurence Preisser ${ }^{1}$, Sophie de Carné Trécesson ${ }^{1}$, Michèle Boisdron-Celle ${ }^{1}$, Erick Gamelin ${ }^{1}$, \\ Olivier Coqueret ${ }^{1}$ and Alain Morel ${ }^{1 *}$
}

\begin{abstract}
Background: Resistance to chemotherapy remains one of the principle obstacles to the treatment of colon cancer. In order to identify the molecular mechanism of this resistance, we investigated the role of the steroid and xenobiotic receptor (SXR) in the induction of drug resistance. Indeed, this nuclear receptor plays an important role in response to xenobiotics through the upregulation of detoxification genes. Following drug treatments, SXR is activated and interacts with the retinoid $X$ receptor (RXR) to induce expression of some genes involved in drug metabolism such as phase I enzyme (like CYP), phase II enzymes (like UGT) and transporters (e.g. MDR1).

Results: In this study, we have shown that endogenous SXR is activated in response to SN-38, the active metabolite of the anticancer drug irinotecan, in human colon cancer cell lines. We have found that endogenous SXR translocates into the nucleus and associates with RXR upon SN-38 treatment. Using ChIP, we have demonstrated that endogenous SXR, following its activation, binds to the native promoter of the CYP3A4 gene to induce its expression. RNA interference experiments confirmed SXR involvement in CYP3A4 overexpression and permitted us to identify CYP3A5 and MRP2 transporter as SXR target genes. As a consequence, cells overexpressing SXR were found to be less sensitive to irinotecan treatment.
\end{abstract}

Conclusions: Altogether, these results suggest that the SXR pathway is involved in colon cancer irinotecan resistance in colon cancer cell line via the upregulation of select detoxification genes.

\section{Background}

One of the challenges in cancer treatment is to understand why some tumors fail to respond to chemotherapy. Delineating in advance the subsets of tumors presenting treatment failure and identifying which pathways are involved in drug resistance would thus represent a significant advance. Several factors contribute to the development of drug resistance. Inadequate drug access to the tumor, drug metabolism and excretion, activation of DNA repair mechanisms, and inactivation of cell death pathways have all been proposed as potential mechanisms used by tumor cells to escape treatment $[1,2]$.

Drug metabolism reactions are divided into three phases: functionalization (phase I enzyme), conjugation

\footnotetext{
* Correspondence: Alain.Morel@ico.unicancer.fr

'Cancer Center Paul Papin, INSERM U892 / University of Angers, 2 rue Moll, Angers, F-49033, France

Full list of author information is available at the end of the article
}

(phase II enzymes), and transport (phase III proteins), but it is essentially carried out by cytochrome p450 3A4 (CYP3A4), which metabolizes more than $50 \%$ of all administered drug [3]. CYP3A4 is the predominant isoform of monooxygenases present in the liver but there is also evidence that metabolism occurs within the tumors that express this isoform, and thereby reduces the efficacy of chemotherapeutic agents $[4,5]$. It has been demonstrated that the transcriptional regulation of the CYP3A4 gene was mediated by the steroid and xenobiotic receptor SXR, also known as the nuclear receptor PXR (pregnane X receptor) [6-9]. SXR is a nuclear receptor mainly expressed in intestine and liver [9]. Following its activation by xenobiotics such as rifampicin, SXR interacts with the retinoid X receptor (RXR) to induce the transcriptional activation of several genes involved in drug metabolism [6,9]. In humans, SXR has been reported to bind the promoter and 
upregulate the expression of several CYPs (CYP3A, CYP2B and CYP2C) [7,9-15], the UDP-glucuronosyltransferase 1A1 (UGT1A1) [16], as well as the xenobiotic transporters multidrug resistance 1 (MDR1) and organic anion transporter $2[17,18]$. For these reasons, SXR is believed to play an important role in the defense against drugs by upregulating the expression of detoxification genes.

Irinotecan (or CPT-11), a camptothecin derivative, is one of the major drugs used in the treatment of colorectal cancers [19]. Irinotecan is a prodrug that forms the pharmacologically active compound 7-ethyl-10-hydroxycamptothecin (or SN-38) via carboxylesterases 1 and 2 (CE1, CE2), but mostly by CE2 [20]. This agent then interacts with DNA topoisomerase I to induce the formation of cleavage complexes that prevent DNA replication. The collision of trapped topoisomerases with DNA replication forks induces DNA double strand breaks that finally lead to cell cycle arrest and cell death [21]. Irinotecan undergoes extensive metabolism: in both the liver and the intestine, it is converted to inactive metabolites by CYP3A4 and CYP3A5 $[5,22]$ while its derivative SN-38 is inactivated through glucuronidation via UGT1A1, UGT1A6, UGT1A7 or UGT1A9 [23]. Irinotecan and its metabolites are also subject to detoxification by different export pumps like MDR1, breast cancer resistance protein (BCRP) and multidrug resistance proteins 1 and 2 (MRP1, MRP2) [24-28]. Since CYP3A4 upregulation is an important mechanism of drug resistance, these observations suggest that the SXR transcription factor could play an important role in tumor escape to irinotecan treatment through the upregulation of CYP3A4 and drug detoxification.

In this study, we identified SN-38, the active metabolite of irinotecan, as a new activator of SXR and elucidated a molecular mechanism by which colon cancer cells might acquire resistance. Upon drug treatment of colon cancer cell lines, SXR is translocated into the nucleus and interacts with RXR. Then, the SXR/RXR heterodimer binds to the promoter of the CYP3A4 gene to induce its expression. As a consequence, cells overexpressing the SXR transcription factor appear to be significantly less sensitive to irinotecan, perhaps due to an enhanced expression of CYP3A4 leading to irinotecan inactivation.

Altogether, these results reveal a complex network of interactions indicating that the SXR pathway induces the expression of detoxification genes in response to the topoisomerase I inhibitor, thereby leading to enhance drug resistance.

\section{Results}

SXR is recruited to the nucleus after SN-38 treatment

In order to determine if SXR is activated by CPT-11, or its active derivative $\mathrm{SN}-38$, we have studied cellular localization of the endogenous nuclear receptor SXR during CPT-11 and SN-38 treatment. Since it has been previously reported that rifampicin stimulates SXRmediated transcription $[6,9]$, this drug was used as a positive control in our cell lines. Following stimulation, cytoplasmic and nuclear extracts were recovered from the colon cancer cell line LS180, used as drug target cell model, and the hepatic cancer cell line HepG2, used as the major site for irinotecan metabolism. Western blot experiments were then performed with antibodies directed against SXR, the nucleus marker histone $\mathrm{H} 3$ and the cytoplasmic marker $\alpha$-tubulin (Figure 1A and 1D). Before drug treatment, SXR was mainly cytoplasmic in LS180 cells and equally distributed between the cytosolic and nuclear compartments in HepG2 cells. We observed that rifampicin activated SXR by inducing its nuclear translocation after a $2 \mathrm{~h}$ stimulation in both cell lines. Interestingly, western blot experiments showed that SN-38 also induced the nuclear translocation of SXR, which was correlated with decreased cytosolic content (Figure 1A). Despite nuclear recruitment being observed in both cell lines after SN-38 and rifampicin treatment, it was stronger in the colon cell line. SXR nuclear recruitment was confirmed by confocal microscopy experiment in LS180 cells after $4 \mathrm{~h}$ exposure to $\mathrm{SN}-38$ (Figure $1 \mathrm{~B}$ ). In order to determine if the SXR activation was an indirect consequence of cell cycle arrest, we performed cell cycle analysis by flow cytometry in LS180 treated with SN-38 (Figure 1C). Cell cycle arrest was not observed until $8 \mathrm{~h}$ drug exposure, indicating that it was not a cause of SXR activation. Moreover, SXR expression was not induced after $4 \mathrm{~h}$ drug exposure, as observed by WB in figure 2 , meaning that the increase of SXR level in the nucleus was not due to its overexpression. No significant variation in SXR localisation was noticed after $8 \mathrm{~h}$ exposure to CPT-11 (Figure 1D).

Thus, we concluded that SN-38 but not CPT-11 induced SXR nuclear recruitment in colon and hepatic cell lines.

\section{SXR interacts with the retinoid $\mathrm{X}$ receptor after $\mathrm{SN}-38$ treatment}

SXR belongs to the same subfamily of nuclear receptors as thyroid hormone receptors (TRs) and retinoic acid receptors (RARs) which form heterodimers with RXR to mediate ligand-dependent transcription [29]. To determine if the nuclear translocation of SXR upon genotoxic treatment induced its association with RXR, LS180 and HepG2 cells were stimulated with $10 \mu \mathrm{M}$ rifampicin, 10 ng/ml SN-38 and $1 \mu \mathrm{g} / \mathrm{ml} \mathrm{CPT-11} \mathrm{during} 4 \mathrm{~h}$. Coimmunoprecipitations were performed with anti-SXR antibody and the proteins present in the immunoprecipitates were revealed by immunoblotting with the RXR antibody (Figure 2). As expected, endogenous SXR and RXR 

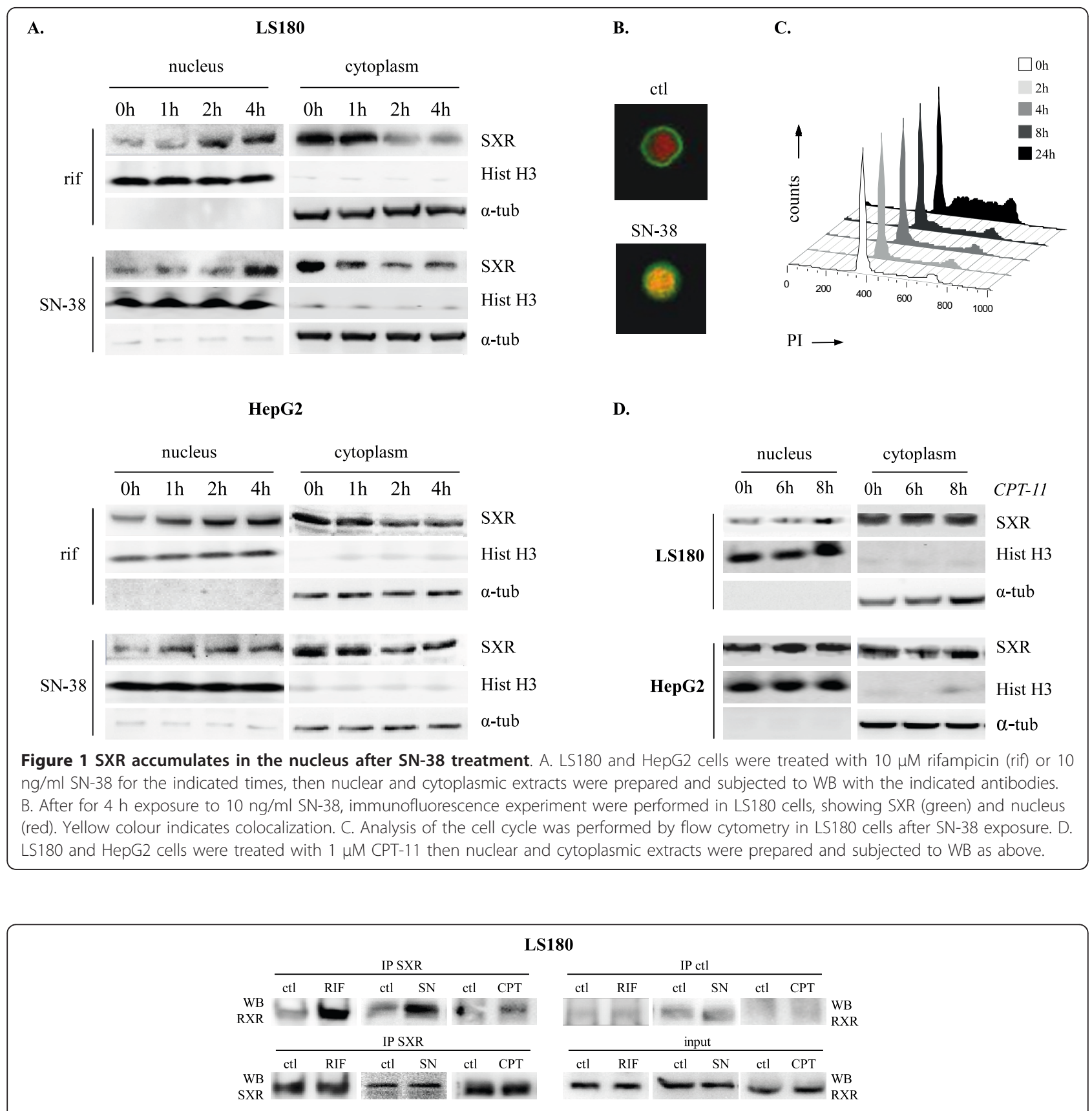

HepG2
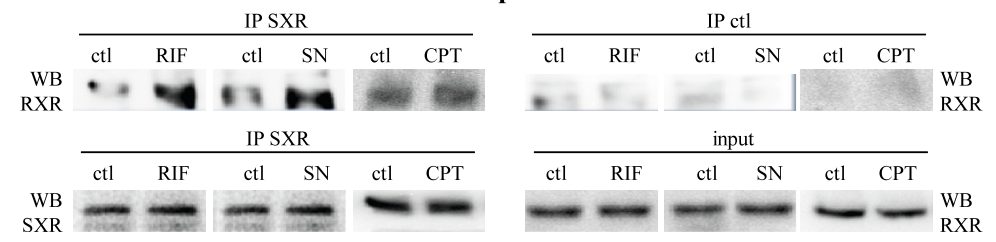

Figure 2 SXR interacts with RXR in cells in a SN-38-dependent manner. LS180 and HepG2 cells were treated with $10 \mu \mathrm{M}$ rifampicin (RIF), 10 $\mathrm{ng} / \mathrm{ml} \mathrm{SN-38} \mathrm{(SN)} \mathrm{or} 1 \mathrm{\mu g} / \mathrm{ml}$ CPT-11 (CPT) for $4 \mathrm{~h}$. Cell extracts were immunoprecipitated (IP) with either lgG (IP control) or anti-SXR (IP SXR) in the presence of vehicle (ctl), rifampicin, SN-38 or CPT-11. Association of the endogenous RXR with the anti-SXR precipitate was detected by WB using anti-RXR antibody. Input indicates endogenous RXR present in 5\% of total cell lysates used in each IP. To ensure equal amounts were precipitated, WB using anti-SXR was also performed. 
were found to co-immunoprecipitate following $4 \mathrm{~h}$ of rifampicin stimulation. Interestingly, the same association was also observed after $4 \mathrm{~h}$ of SN-38 treatment. This interaction was dependent on the presence of the drugs since a very weak interaction was detected between the two proteins in non-stimulated cells. No interaction between SXR and RXR was observed after 4 $\mathrm{h}$ of CPT-11 exposure in both cell lines (Figure 2).

We infer from these results that SXR interacted with RXR upon SN-38 treatment in LS180 and HepG2 cells whereas no interaction has been reported after CPT-11 treatment.

\section{SXR interacts with the native cytochrome p450 3A4 promoter after $\mathrm{SN}-38$ treatment}

The formation of heterodimers between SXR and RXR is expected to mediate DNA binding to xenobioticresponse elements (XREs) present on SXR target genes such as CYP3A4. To verify this observation, we determined by chromatin immunoprecipitation (ChIP) experiments whether $\mathrm{SN}-38$ treatment induced the binding of the transcription factor to one of its target genes, namely the CYP3A4 promoter. Two XREs were previously found at the $-7773 /-7719$ and $-169 /-150$ regions of the promoter and were named binding site 1 and 2 respectively (Figure 3A). Previous studies had shown that the two SXR binding sites worked in a synergistic way but could induce CYP3A4 transcription separately. Nevertheless, the binding site 2 was necessary to the maximal activation $[7,9]$.

Chromatin was prepared using a formaldehyde crosslinking protocol and occupancy of the promoter was analyzed using specific pairs of primers spanning the two XREs. As controls, PCR analysis was also performed with a third set of primers spanning a promoter unrelated region (Figure $3 \mathrm{~A}$ ), and immunoprecipitations were conducted with irrelevant IgG to ensure the specificity of the reaction. As expected, antibodies directed against SXR precipitated DNA encompassing the two SXR responsive elements of the CYP3A4 promoter following rifampicin stimulation. Importantly, we also observed that SXR was recruited to both XREs upon SN-38 treatment but not upon CPT-11 treatment (Figure 3B). As a control, PCR analysis did not detect any occupancy of the control region located on the CYP3A4 promoter. Quantitative PCR analysis indicated that SXR bound with the same affinity to the two XREs (Figure 3C).

Increased binding of the transcription factor is expected to facilitate the recruitment of the RNA polymerase II to the CYP3A4 promoter. To test this hypothesis, ChIP experiments were also performed using antibodies directed against the RNA polymerase II and its active phosphorylated form. As expected, quantitative PCR analysis indicated that the total RNA polymerase II as well as the phosphorylated form were recruited to the both SXR binding sites on CYP3A4 promoter after SN38 stimulation. Similar results were obtained by using primers spanning the transcription start site (data not shown). The binding of RNA polymerase was detected on both XREs, suggesting that the recruitment of SXR could induce cooperative DNA binding and the formation of a functional enhanceosome.

Altogether, these results indicate that the SXR transcription factor bound to the native promoter of the CYP3A4 gene in association with the activated RNA polymerase II upon SN-38 treatment, but not upon CPT-11 treatment.

\section{SXR is involved in the SN-38-mediated upregulation of select irinotecan detoxification genes}

To extend our results, we investigated the role of SXR in regulation of the genes involved in irinotecan metabolism. We first identified by RT-qPCR which detoxification genes were upregulated after CPT-11 and SN-38 treatment and then, after SXR expression inhibition, we determined which of the upregulated genes were induced by activation of the nuclear receptor.

To this end, LS180 and HepG2 cells were treated during $24 \mathrm{~h}$ with CPT-11 and SN-38. Quantitative PCR experiments were then performed to detect the mRNA expression of the irinotecan metabolism phase I genes (CYP3A4, CYP3A5), the main irinotecan metabolism phase II genes (UGT1A1, UGT1A7) and the irinotecan transporters genes (MDR1, MRP1, MRP2 and BCRP). As presented in figure 4, in LS180 cells, SN-38 induces a strong increase in CYP3A4 and CYP3A5 transcription (respectively 6 and 13 times) and a weaker effect was observed for UGT1A1, UGT1A7 and MRP2 ( 2-3 times) while CPT-11 treatment has no effect. In HepG2 cells, upon SN-38 treatment, CYP3A4, CYP3A5, MDR1 and BCRP mRNA were increased 4 times, UGT1A1 6 times and MRP1 two fold, whereas only UGT1A1 and BCRP genes were upregulated ( 2-3 times) after CPT-11 treatment.

We then investigated the role of SXR on the CPT-11 and SN-38-mediated upregulated genes. To this end, LS180 and HepG2 cells were transiently transfected with control siRNA or siRNA targeting SXR prior to stimulation. As shown in figure 5A, siRNA transfection resulted in a significant reduction in SXR levels in LS180 cells (79\% protein inhibition, measured by densitometry and relative to GAPDH expression) and a weaker reduction in HepG2 (55\% inhibition). Interestingly, in LS180 cells, SXR knockdown led to a 50\% decrease of MDR1 and MRP1 basal expression (Figure 5B). No significant effect of SXR downregulation was noticed on the basal expression of all the genes tested in HepG2. Moreover, reduction of SXR levels by siRNA prevented the upregulation of CYP3A4 and CYP3A5 following SN-38 treatment in 
A.

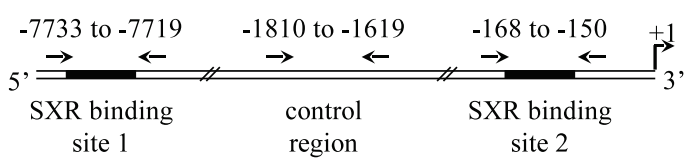

B.

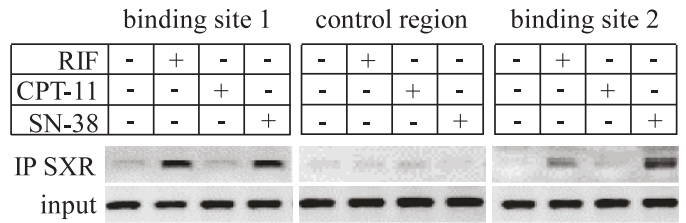

C.

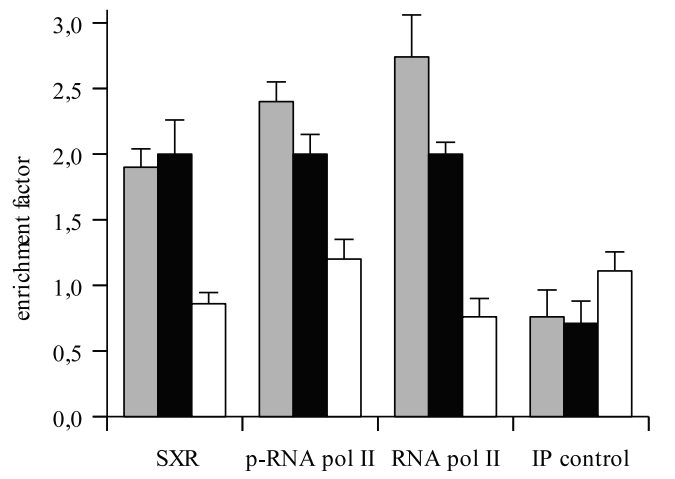

HepG2

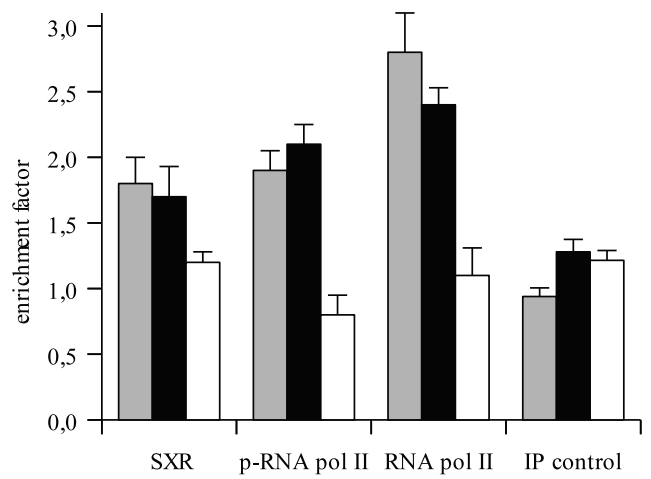

Figure 3 SN-38 treatment induces binding of endogenous SXR to the native CYP3A4 promoter. A. ChIP assays were performed and DNA was further analyzed either by classical PCR or by semi-quantitative PCR using a primer set specific for the promoter or control region as indicated by the arrows on the schematic diagram of the CYP3A4 promoter. B. LS180 were treated with $10 \mu \mathrm{M}$ of rifampicin (rif), $1 \mu \mathrm{g} / \mathrm{ml}$ CPT-11

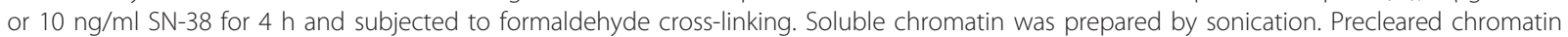
solution was immunoprecipitated by antibodies anti-SXR or lg control, and precipitated. PCR was performed with the precipitated DNA (IP SXR) or the DNA present in 10\% of total cell lysates used for each IP (input). C. Cells were treated with SN-38 for $4 \mathrm{~h}$ and subjected to ChIP as described above with anti-SXR, anti-RNA phospho-ARN polymerase II and anti-RNA polymerase II. Enrichment factors were determined by qPCR using GAPDH as threshold indicator (internal control for each IP).

LS180 (Figure 5C). The other tested genes showed no appreciable expression change after SXR downregulation (data not shown). In HepG2 cells, we observed that SXR knockdown blunted the SN-38-induced expression of most of the genes involved in irinotecan metabolism (Figure 5C). In addition, SXR downregulation had no effect on CPT-11-induced gene expression (data not shown).

Altogether, these results indicate that the SXR transcription factor activated the expression of the CYP3A4 and CYP3A5 gene in response to $\mathrm{SN}-38$ in HepG2 and LS180 cells. MDR1 and MRP1 expression also appeared to be regulated by SXR in both cell lines while UGT1A1 and BCRP gene were regulated in a cell dependent manner.

\section{SXR promotes CPT-11 resistance in some colon cancer cell lines}

Since it is CPT-11 and not SN-38 which is converted to inactive metabolites through CYP3A4 and CYP3A5, the SXR-mediated upregulation of these genes should prevent the effect of CPT-11 on cell death. As a consequence, cells overexpressing SXR should be less sensitive to the topoisomerase inhibitor. To test this hypothesis, LS180 cells and HCT116 cells, another colon cancer cell line which not express SXR, were transiently transfected with SXR or control expression vectors for $24 \mathrm{~h}$, then treated with increasing concentrations of irinotecan for $72 \mathrm{~h}$ (Figure 6). We first verified that the cells expressed the CE2 needed for CPT-11 conversion to the SXR activator SN-38 (Figure $6 \mathrm{~A})$. Then, the cytotoxicity assays confirmed that CPT-11 induced a dose-dependent decrease of cell survival in control conditions and that overexpression of SXR significantly reduced irinotecan induced cell death in LS180 cells (Figure 6B), as well as in HCT116 cells (Figure 6C).

Altogether, these results suggest that SXR overexpression limited the effect of CPT-11 on colon cancer cell death.

\section{Discussion}

In addition to the regulation of tumor suppressor networks and DNA repair pathways, the ability of cancer cells to survive genotoxic treatments also relies on the 


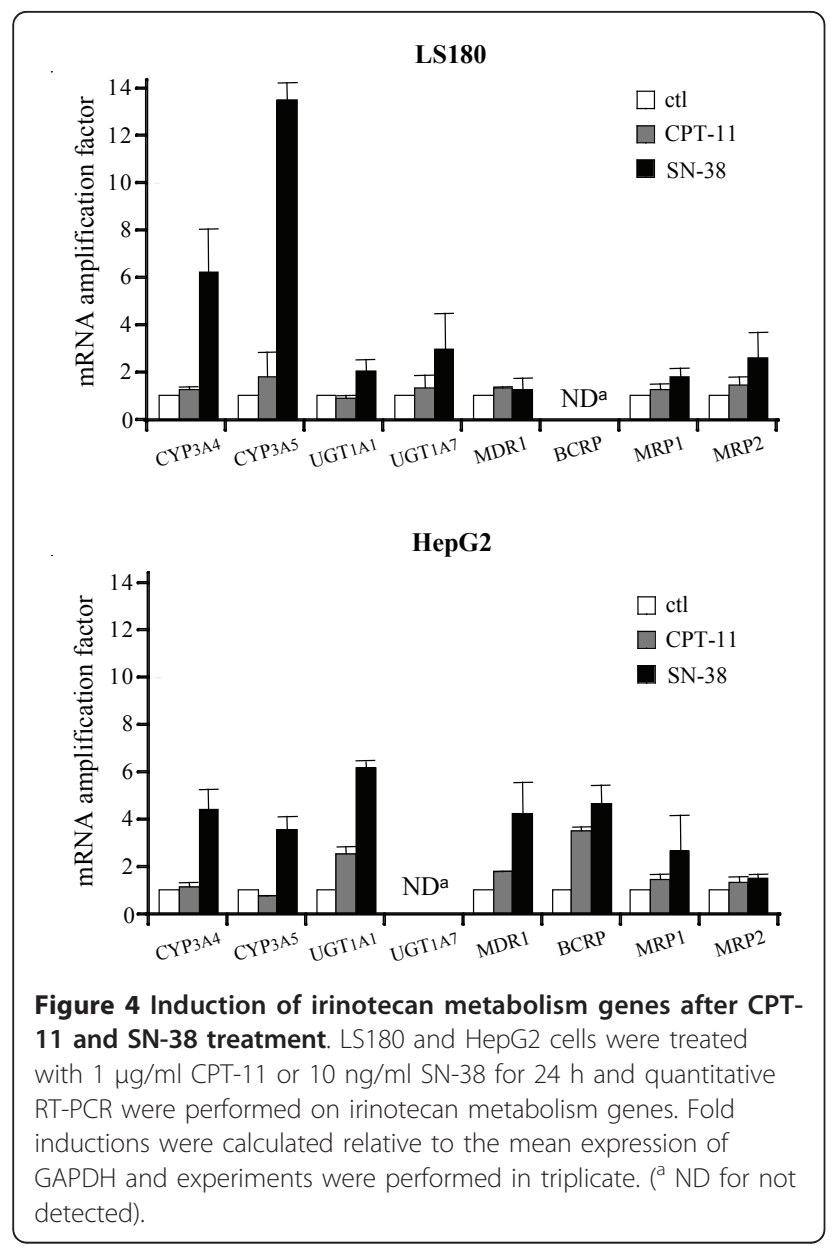

efficacy of their detoxification pathways. In this study, we show for the first time that the nuclear receptor SXR is activated by $\mathrm{SN}-38$, the active derivative of irinotecan, whereas CPT-11 itself is a very weak activator. Upon SN-38 treatment, endogenous SXR translocates into the nucleus, interacts with RXR and the so-formed heterodimer binds the CYP3A4 promoter, allowing the recruitment of the RNA polymerase and the expression of the CYP3A4 gene. These molecular mechanisms operate in colon cancer cells, a target of irinotecan treatment as well as in liver cancer cells, a major site of irinotecan metabolism.

Moreover, we show that LS180 colon cancer cells that overexpress SXR are less sensitive to CPT-11 treatment compared to control cells, indicating that this transcription factor is involved in drug resistance, probably through CYP3A4, CYP3A5, MDR1 and MRP1 upregulation. In light of these observations, we propose a feedback model (Figure 7) in which the SXR-CYP3A pathway is induced in response to irinotecan treatment in colon cancer cells, SXR mediated expression of detoxification genes allowing for drug resistance and tumor escape to genotoxic treatments.

We observe some differences between the LS180 and HepG2 cellular models. Indeed, expression analyses of irinotecan detoxification genes (CYP3A, UGT1A and $\mathrm{ABC}$ transporters) show that most of these genes are induced upon SN-38 treatment, but their expression pattern varies depending on cell type. Furthermore, we find that HepG2 cells are more resistant to treatment:
A. SXR expression

B. basal gene expression

LS180
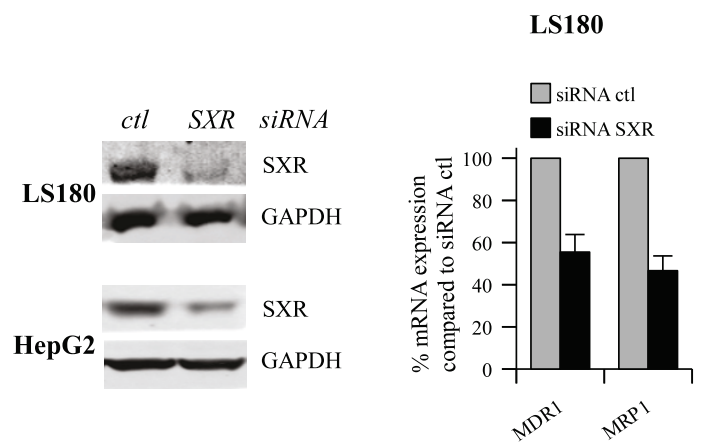

C. SN-38 induced gene expression
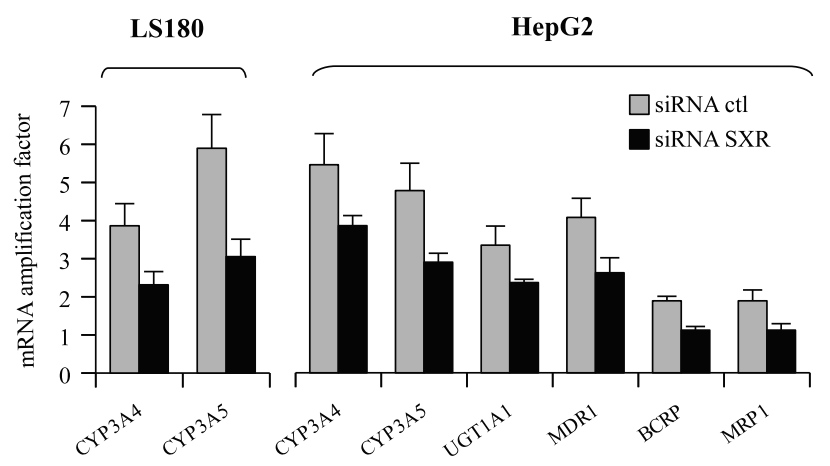

Figure 5 SXR involvement in induction of irinotecan metabolism genes. A. Detection of SXR by western blot in LS180 and HepG2 cells after $48 \mathrm{~h}$ siRNA transfection. B. After $48 \mathrm{~h}$ siRNA transfection, cells were cultivated for $24 \mathrm{~h}$ in new medium and mRNA levels of the irinotecan metabolism genes were determined. Data represent percentage of mRNA levels after siRNA-SXR transfection compared to siRNA-control transfection. C. After $48 \mathrm{~h}$ siRNA transfection, cells were stimulated with $10 \mathrm{ng} / \mathrm{ml} \mathrm{SN}-38$ for $24 \mathrm{~h}$ and mRNA levels were determined. Data represent fold induction of mRNA levels compared to untreated cells. 


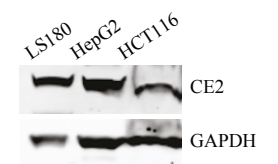

B.
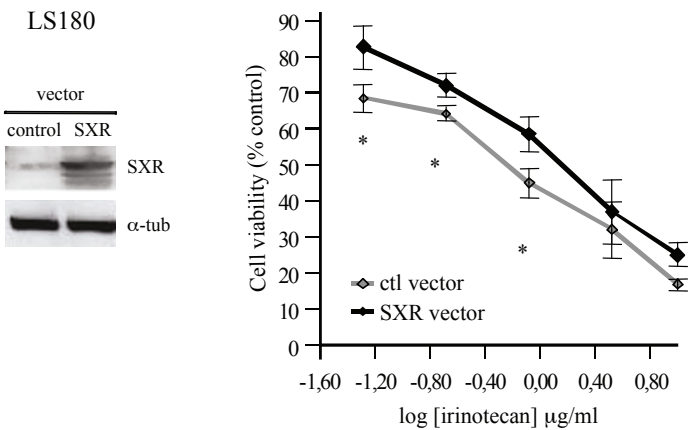

C. HCT116
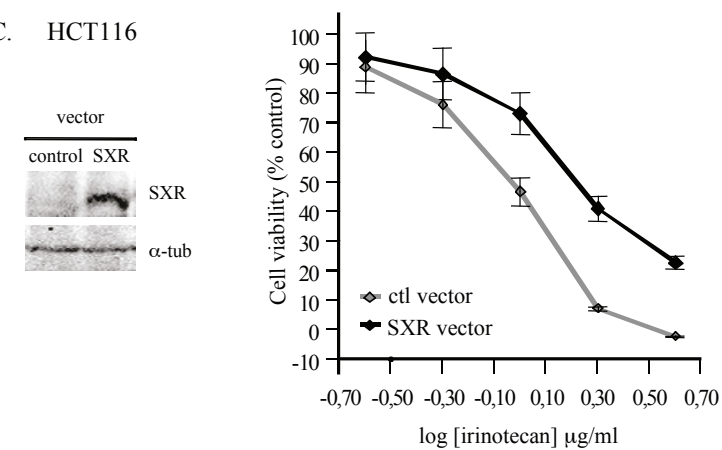

Figure 6 Effect of SXR overexpression on LS180 and HCT116 survival after SN-38 treatment. A. Detection of carboxylesterase 2 (CE2) by western blot in LS180, HepG2 and HCT116 cells. B. and C. LS180 cells (B) and HCT116 cells (C) were transfected with control or SXR vector for $24 \mathrm{~h}$, then treated for $72 \mathrm{~h}$ with different CPT-11 concentrations. The SXR overexpression was confirmed by western blot after $24 \mathrm{~h}$ transfection. Cell viability following irinotecan exposure was determined by SRB assay by comparison with untreated cells. Each point represents the mean of 3 replicates and the experiment has been repeated 3 times. All results are expressed as the mean \pm SE and obtained data were analysed for statistical differences by Student's $t$ test. A p value of less than 0.05 was considered statistically significant (star indicates $p<0.05$ ).

after $72 \mathrm{~h}$ incubation, IC50 values are 3.7 -fold higher for CPT-11 and 5-fold higher for SN-38 in HepG2 than in LS180 cells (data not shown). This discrepancy can be explained by the upregulation of a large number of detoxification genes in the hepatic model, leading to stronger drug inactivation.

Moreover, SXR knockdown blunted but not abrogated the increase of the select genes that were induced by SN-38 treatment. We can hypothesize that the gene transcription could be induced by other transcription factors in addition to SXR. Thereby, the absence of SXR could allow other constitutively active nuclear receptors to access SXR target gene promoters. For example, it

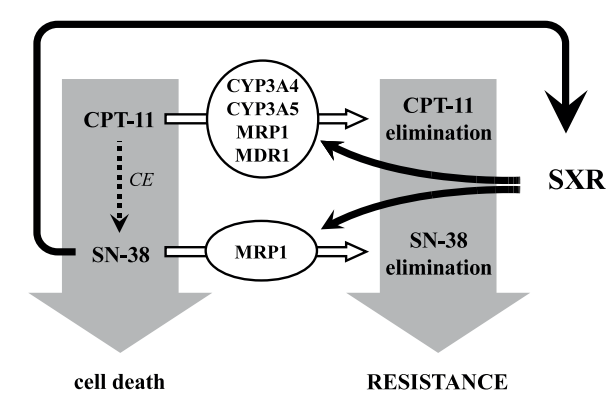

Figure 7 Proposed model for the SXR-mediated response to irinotecan in colon cancer cells. In LS180 cells, CPT-11 is metabolized to SN-38 by the carboxylesterases (CE). SN-38 induces the activation of SXR. Consequently, the transcription factor is recruited to the CYP3A4 and CYP3A5 promoter and upregulates the expression of these genes. SXR also constitutively activates MDR1 and MRP1 expression. As a feedback loop, CYP3A4, CYP3A5 and the transporters reduce the concentration of active irinotecan inside the cell, which favors cell proliferation. As a consequence, we propose that the combined detection of SXR together with a high expression of CYP3A4 should help to define in advance the subsets of tumors that will fail to respond to chemotherapy based on irinotecan treatment.

has been demonstrated that CAR and SXR can be activated by some common ligands and induce the same genes (CYP3A and CYP2B) by using the same consensus sites [30]. Other studies have established that FXR and VDR could share some target gene binding sites with SXR (reviewed by Zhou et al. [31]). All these receptors are mainly expressed in liver and/or colon cells.

It is interesting to note that gene regulation by SXR depends not only on the cell line but also on the SXR activator drug. For example MDR1, which is known to be a SXR target gene, does not exhibit any expression change after SN-38 treatment in LS180 whereas it is strongly induced by SXR upon rifampicin stimulation in the same cells (data not shown). Masuyama et al. [32] explain this specificity of gene induction by involvement of transcription co-activator proteins. Depending on the ligand, SXR would interact with different co-activators, leading to the induction of specific genes. In addition, Zhou et al. [33] have demonstrated that different corepressors could also be involved in tissue-specific gene induction by SXR.

Surprisingly, if SN-38 is a SXR activator, CPT-11 is not. Assuming that there is a direct binding of these compounds on SXR, specific activation could be due to differences in ligand affinities for the receptor. This is surprising considering the very close structure of these two compounds and the SXR ligand binding pocket ability to welcome a great number of chemically different molecules [34]. Such differences have already been 
described between paclitaxel and docetaxel [35]. The weak impact of CPT-11 on metabolism gene induction could be due to its requirement to be converted into its active form SN-38 by CE2, which is expressed in HepG2 and LS180 cells. Moreover, Xu et al. [36] have evaluated CE2 expression in different tumors and have shown that $66 \%$ of tumor tissues expressed CE2 and that conversion of CPT-11 to SN-38 was correlated with the enzyme expression.

Knowing that detoxification is not the only mechanism involved in resistance to irinotecan, it will be interesting to determine if other genes are involved in the SXR mediated resistance. We have showed that the target gene (TOPO1) expression was not modified after treatment (data not shown). Irinotecan resistance could also be related to the changes of expression of DNA repair genes, cell cycle genes, cell death and survival pathway genes. Recently, two teams studied the antiapoptotic role of SXR in some cancer cell lines [37,38]. They both demonstrated that overexpressed SXR in human cell lines protected against induced apoptosis and promoted drug resistance in connection with the upregulation of some anti-apoptotic genes and downregulation of several pro-apoptotic genes. Nevertheless, other studies reported a pro-apoptotic role of human SXR in breast cancer cells [39] or in colon cancer cells [40] but, as seen in a previous paragraph, this difference of gene regulation can be explained respectively by celltype specificity and ligand specificity of SXR induction.

We have observed that SXR is involved in irinotecan detoxification. Other studies implicating SXR in anticancer drug detoxification like paclitaxel, cisplatin, tamoxifen or etoposide are already available [35,41-44]. Its involvement in resistance to paclitaxel and vinblastine in prostate cancer is clearly observed by Chen et al. [45]. In addition, a recent study showed that SXR was overexpressed in colon cancer tissues and suggested that the nuclear receptor may play role in resistance to 5-fluorouracil and oxaliplatin, two drugs used in treatment of colorectal cancer [46]. Those data clearly corroborate our work by demonstrating the influence of SXR on antineoplastic agents.

In addition, the ability of SXR to be activated by diverse therapeutic compounds places it as a major component in drug-drug interaction. This nuclear receptor is induced by a wide range of drugs: the antibiotic rifampicin, the anticancer drugs cited above, the barbiturate phenobarbital, the corticoid dexamethasone, the HIV protease inhibitor ritonavir or the antidepressant hyperforine [9,47-49]. Consequently, during a coadministration, SXR activation, leading to the induction of its target genes, could cause an accelerated metabolism of one of the drugs by the CYP3A4. This could lead to a diminution of clinical efficacy and could be at the origin of strong resistances. For example, a drugdrug interaction has been observed in some patients with glioma who have received $\mathrm{CPT}-11$ and dexamethasone $[50,51]$. The discovery of SN-38 as a new activator of SXR may help prevent some cases of drug-drug interaction unsuspected until now. Considering that one of the SXR target gene, CYP3A4, is alone responsible for the metabolism of more than $50 \%$ of the drugs currently administrated, the search of novel partners of SXR is clearly relevant.

\section{Conclusions}

All together, these results uncover new functions for the SXR pathway in the understanding of resistance to irinotecan. Our results suggest that tumors expressing SXR might be more resistant to anticancer treatment. We therefore propose that the SXR pathway should be considered as a valuable tool to predict the subsets of tumors that will fail to respond to chemotherapy.

\section{Methods}

\section{Cell lines and treatment}

LS180, HepG2 and HCT116 cells were purchased from the ATCC (Manassas, VA, USA). Experiments were done in MEM supplemented with $10 \%$ fetal bovine serum (Invitrogen, Carlsbad, CA, USA). Rifampicin and irinotecan were purchased from Sigma-Aldrich (St. Louis, MO, USA) and SN-38 from Aventis (Bridgewater, NJ, USA).

\section{Nuclear and cytoplasmic and total extracts}

The cell pellets were suspended in buffer A (10 mM Hepes pH 7.9, $10 \mathrm{mM} \mathrm{KCl,} 1.5 \mathrm{mM} \mathrm{MgCl2}$ ), kept on ice for $15 \mathrm{~min}$, then subjected to 3 freeze-thaw cycles. The nuclei were pelleted by centrifuging at $400 \mathrm{~g}$ for 5 min at $4^{\circ} \mathrm{C}$ while supernatant was conserved as cytoplasmic fraction. Nuclei were washed with $1 \mathrm{ml}$ buffer $\mathrm{A}$, centrifuged at $400 \mathrm{~g}$ for $5 \mathrm{~min}$ at $4^{\circ} \mathrm{C}$, resuspended in buffer C (20 mM Hepes, $420 \mathrm{mM} \mathrm{KCl,} 1.5 \mathrm{mM} \mathrm{MgCl} 2$, $0.2 \mathrm{mM}$ EDTA, 25\% glycerol) and kept on ice for 30 min. The nuclear fraction was then submitted to $10 \mathrm{~s}$ pulse sonication, centrifuged at $14000 \mathrm{~g}$ and supernatant were collected.

For total extract, cells were lysed in buffer $\mathrm{C}$ and incubated for $30 \mathrm{~min}$ on ice. Lysates were submitted to $10 \mathrm{~s}$ sonication and centrifugated at $15000 \mathrm{~g}$ during $5 \mathrm{~min}$. Supernatant was collected and protein concentrations were determined by the Bradford method with Bio-Rad's Protein Assay Reagent (Bio-Rad, Hercules, CA) using BSA standards (Pierce, Rockford, IL).

\section{Western Blot}

Protein extracts were loaded on 10\% SDS/PAGE gels then proteins were transferred to PVDF membranes. 
The membranes were blocked with $5 \%$ defatted milk for $1 \mathrm{~h}$, immunoblotted overnight at $4^{\circ} \mathrm{C}$ with anti-SXR (Santacruz Biotechnology, Santa Cruz, CA, USA or Abcam, Cambridge, MA, USA), anti-histone H3 (Cell Signaling, Beverly, MA, USA), anti- $\alpha$-tubulin (Sigma), or anti-GAPDH (American Research Products, Belmont, MA, USA), then incubated with the secondary HRPconjugated antibody. Bands were visualized using ECL detection reagents (Amersham Biosciences, Pittsburgh, PA, USA) and quantified with the ChemiDoc ${ }^{\mathrm{TM}}$ XRS imager (Bio-Rad, Hemel Hempstead, UK).

\section{Immunofluorescence}

LS180 cells were fixed with $2 \%$ paraformaldehyde in PBS for $30 \mathrm{~min}$ at room temperature then permeabilized for $30 \mathrm{~min}$ in $70 \%$ ethanol. After blocking with 1\% BSA, indirect immunostaining was performed using an antiSXR antibody (Santa Cruz Biotechnology) and a fluorescein isothiocyanate-conjugated secondary antibody (Santacruz Biotechnology). Nuclei were stained with propidium iodide. Cells were observed using an Olympus confocal microscope (Olympus, Rungis, France), with high magnification (x630).

\section{Cell cycle assay}

LS180 cells were permeabilised and fixed with ethanol $70 \%$, treated with RNase A for $30 \mathrm{~min}$ at $37^{\circ} \mathrm{C}$ then incubated $5 \mathrm{~min}$ with propidium iodide. Cell cycle analysis was performed on a FACSort flow cytometer (BD Biosciences, San Jose, CA, USA) and data were analysed with Flowjow software (TreeStar, Inc., Ashland, OR, USA).

\section{Coimmunoprecipitation Assays}

HepG2 and LS180 cells were treated with $10 \mu \mathrm{M}$ rifampicin, $1 \mu \mathrm{g} / \mathrm{ml} \mathrm{CPT-11}$ or $10 \mathrm{ng} / \mathrm{ml} \mathrm{SN}-38$ for $4 \mathrm{~h}$. Harvested cells were suspended in lysis buffer $(20 \mathrm{mM}$ Hepes pH 8, 0.2 mM EDTA, 5\% glycerol, $100 \mathrm{mM}$ $\mathrm{NaCl}, 0.1 \%$ nonidet $\mathrm{P}-40,0.25 \%$ sodium deoxycholate, 1 $\mathrm{mM} \mathrm{NaF}, 1 \mathrm{mM}$ sodium orthovanadate, $1 \mathrm{mM}$ DTT). After $10 \mathrm{~min}$ incubation on ice followed by sonication and centrifugation, cell extracts were precleared by incubation for $30 \mathrm{~min}$ at $4^{\circ} \mathrm{C}$ with $20 \mu$ protein $\mathrm{G}$ sepharose - 50\% slurry (Amersham). After centrifugation, mix was incubated with $1 \mu \mathrm{g}$ of anti-SXR or anti-RXR (Santa Cruz Biotechnology) for overnight at $4^{\circ} \mathrm{C}$. Immune complexes were collected by incubation with $20 \mu$ protein $\mathrm{G}$ sepharose for $1 \mathrm{~h}$ and were washed five times with lysis buffer. CPT-11, SN-38 or rifampicin were added during immunoprecipitation and washing steps.

\section{Chromatin Immunoprecipitation}

Cells were rinsed in PBS, cross-linked by adding formaldehyde (1\% in PBS) for $10 \mathrm{~min}$ and the reaction was stopped with $125 \mathrm{mM}$ glycine for $5 \mathrm{~min}$. After two rinses, cells were scraped in lysis buffer (1\% SDS, 10 $\mathrm{mM}$ EDTA, $50 \mathrm{mM}$ Tris- $\mathrm{HCl} \mathrm{pH} \mathrm{8.1)} \mathrm{and} \mathrm{lysate} \mathrm{was}$ subjected to sonication for four 15 -second pulses and centrifuged at $14000 \mathrm{~g}$ for $15 \mathrm{~min}$ at $4^{\circ} \mathrm{C}$. The supernatant was diluted 2-fold in buffer (150 mM NaCl, $50 \mathrm{mM}$ Hepes pH 7.9, 1\% triton-X100, 0.1\% SDS, 2 mM EDTA) and precleared by adding $2 \mu \mathrm{g}$ of salmon sperm DNA and $20 \mu$ l Protein G sepharose, and rotating for $1 \mathrm{~h}$ at $4{ }^{\circ} \mathrm{C}$. After a brief centrifugation, the supernatant was incubated with $1 \mu \mathrm{g}$ anti-SXR, anti-RNA polymerase II or anti-phospho-RNA polymerase II (Abcam) overnight at $4{ }^{\circ} \mathrm{C}$. The following day, the immune complexes were collected by adding $20 \mu$ l Protein G sepharose and incubating for $1 \mathrm{~h}$ at $4^{\circ} \mathrm{C}$, followed by a centrifugation. The pellet was sequentially washed with low-salt- (150 mM $\mathrm{NaCl}, 50 \mathrm{mM}$ Hepes pH 7.9, 0.1\% SDS, 1\% triton X100, 2 mM EDTA), high-salt- (500 mM NaCl, $50 \mathrm{mM}$ Hepes pH 7.9, 0.1\% SDS, 1\% triton X-100, $2 \mathrm{mM}$ EDTA), and LiCl- (20 mM tris pH 8.1, 1\% NP-40, 1\% deoxycholate, $250 \mathrm{mM} \mathrm{LiCl}, 1 \mathrm{mM}$ EDTA) wash buffers and rinsed with TE buffer. The immune complexes were eluted by 20 min incubation with $1 \%$ SDS and $0.5 \mathrm{M}$ $\mathrm{NaHCO} 3$. The formaldehyde-induced cross-links were reversed by adding $\mathrm{NaCl}$ to a final concentration of 5 $\mathrm{mM}$ and incubating at $65^{\circ} \mathrm{C}$ for $4 \mathrm{~h}$. DNA was then purified using standard phenol/chloroform method. Classical or real-time PCR were carried out with primers amplifying control promoter region or SXR binding sites at $-169 \mathrm{bp}$ and $-7734 \mathrm{bp}$ from the transcriptional start site of CYP3A4 gene. Data obtained from immunoprecipitated samples were compared with input for classical PCR and normalized to values obtained with the housekeeping gene GAPDH for qPCR.

\section{RNA extraction and RT-PCR}

After 24 h treatment, total RNA was isolated from cells by the acid guanidinium isothiocyanate-phenol-chloroform extraction method [52]. For reverse transcription, $1.3 \mu \mathrm{g}$ of random hexamers (Amersham) were added to $2 \mu \mathrm{g}$ of total RNA in a total volume of $15 \mu \mathrm{l}$. The mixture was incubated for $5 \mathrm{~min}$ at $70^{\circ} \mathrm{C}$ and then chilled on ice. $4 \mathrm{U} / \mu \mathrm{l}$ of MMLV, $4 \mathrm{mM}$ dNTPs, $1 \mathrm{X}$ MMLV buffer and $0.8 \mathrm{U} / \mu \mathrm{l}$ of RNasin (Invitrogen) were added and the whole mixture $(50 \mu \mathrm{l})$ was further incubated at $37^{\circ} \mathrm{C}$ for $1 \mathrm{~h}$. Real-time PCR was carried out as describe above. PCR was realized with $5 \mu \mathrm{l}$ of $1 / 20 \mathrm{cDNA}$ dilution in a final volume of $10 \mu \mathrm{l}$. Total RNA which has not been reverse-transcripted was amplified and used as DNA-free RNA sample control.

\section{Semi-quantitative PCR}

Real-time PCR was carried out using the LightCycler System (Roche Applied Science, Mannheim, Germany). 
PCR was set up at $4 \mathrm{mM} \mathrm{MgCl} 2,5 \mu \mathrm{M}$ of each primer (MWG Biotech, Huntsville, AL, USA), $5 \mu$ l of recover DNA and $1 \mathrm{X}$ of Master Mix (Roche) in a final volume of $10 \mu \mathrm{l}$. Data analysis was essentially performed using "Fit Point Method" in the LightCycler software version 3.5.3. Relative quantification was performed using the comparative Cycle Threshold (CT) method by Fink et al [53]. DNA enrichment quantification or mRNA amplification factor were calculated relative to the presence of GAPDH gene, according to the following equation: $\mathrm{EF}=$ $2^{-\Delta \Delta C T}$ where $\Delta \Delta C T=\left[\mathrm{CT}_{\text {promoter region }}-\mathrm{CT}_{\mathrm{GAPDH}}\right]_{\mathrm{drug}}$ - $\left[\mathrm{CT}_{\text {promoter region }}-\mathrm{CT}_{\mathrm{GAPDH}}\right]$ no treatment for ChIP experiment, and where $\Delta \Delta \mathrm{CT}=\left[\mathrm{CT}_{\text {target }}\right.$ gene $^{-}$ $\left.\mathrm{CT}_{\mathrm{GAPDH}}\right]_{\text {drug }}-\left[\mathrm{CT}_{\text {target gene- }}-\mathrm{CT}_{\mathrm{GAPDH}}\right]_{\text {no treatment }}$ for RT-PCR experiment.

The factor was determined from the average of 3 experiments. The sequences of PCR primers are available upon request.

\section{SXR transcription inhibition}

siRNA experiments were carried out with Dharmafect reagent (Thermo Scientific Dharmacon, Lafayette, CO, USA) in LS180 cells, according to the manufacturer's protocol. Cells were transfected $48 \mathrm{~h}$ prior treatment with $25 \mathrm{nM}$ siRNA against SXR (SMARTpool Dharmacon) and corresponding amount of siRNA control. SMARTpool is a mixture of four individual siRNA.

HepG2 cells were transfected with $5 \mathrm{nM}$ siRNA from QIAgen (Hilden, Germany) using HiPerfect reagent following manufacturer's instruction (Qiagen). Transfection were performed $48 \mathrm{~h}$ and $24 \mathrm{~h}$ before treatment.

Target protein expression was controlled by western blot $48 \mathrm{~h}$ after siRNA transfection, prior the $24 \mathrm{~h}$ drug treatment.

\section{SRB assay and statistical analysis}

The major SXR transcript variant (SXR.1, [54]) cDNA was isolated from human liver cDNA library (Takara Bio Inc., Shiga, Japan) and cloned into the pcDNA3.1 vector (Invitrogen). Cells were transfected with pcDNA3.1-SXR or pcDNA 3.1-control $24 \mathrm{~h}$ before treatment. Then, different dilutions of CPT-11 were added to cells and cell survival was measured after $72 \mathrm{~h}$ with the sulforhodamine B assay [55]. Each point represents the mean of 3 replicates and the experiment was repeated 3 times. All results are expressed as the mean $\pm \mathrm{SE}$ and data were analyzed for statistical differences by Student's $t$ test. A p-value of less than 0.05 was considered statistically significant.

\section{List of abbreviations}

The abbreviations used are: SXR: steroid and xenobiotic receptor; CYP: cytochrome p450; RXR: retinoid X receptor; UGT: UDP-

glucuronosyltransferase; MDR: multidrug resistance; CPT-11: irinotecan; SN-38: 7-ethyl-10-hydroxycamptothecin; CE: carboxylesterase; BCRP: breast cancer resistance protein; MRP: multidrug resistance protein; CAR: constitutive androstane receptor; FXR: farnesoid X receptor; VDR: Vitamin D Receptor.

\section{Acknowledgements}

We wish to thank Anne Lise Poirier for her statistical expertise and Dr Susan Bates for allowing us to complete the experiments in her lab. This work was supported by grants from the Ligue Contre le Cancer (équipes labelisées 2007, O.C. and E.G. and comité du Maine et Loire).

\section{Author details}

'Cancer Center Paul Papin, INSERM U892 / University of Angers, 2 rue Moll, Angers, F-49033, France. 'Medical Oncology Branch, Center for Cancer Research, National Cancer Institute, National Institues of Health, 9000 Rockville Pike, Bethesda, MD 20892, USA.

\section{Authors' contributions}

$A B$ carried out the experiments and drafted the manuscript. LP carried out some ChIP assay, some siRNA assay and some survival assay. SCT carried out the WB for siRNA and transfection assays. MBC and EG participated in the conception and design of the study. OC participated in the conception of the study, its design and helped to draft the manuscript. AM conceived of the study, participated in its design and coordination, and helped to draft the manuscript. All authors read and approved the final manuscript.

\section{Competing interests}

The authors declare that they have no competing interests.

Received: 8 June 2010 Accepted: 6 July 2011 Published: 6 July 2011

\section{References}

1. Kruh GD: Introduction to resistance to anticancer agents. In Oncogene Volume 22. England; 2003:7262-7264.

2. Gottesman MM, Fojo T, Bates SE: Multidrug resistance in cancer: role of ATP-dependent transporters. Nat Rev Cancer 2002, 2:48-58.

3. Xu C, Li CY, Kong AN: Induction of phase I, II and III drug metabolism/ transport by xenobiotics. Arch Pharm Res 2005, 28:249-268.

4. Plant $\mathrm{N}$ : The human cytochrome P450 sub-family: transcriptional regulation, inter-individual variation and interaction networks. In Biochim Biophys Acta. Volume 1770. Netherlands; 2007:478-488.

5. Scripture CD, Sparreboom A, Figg WD: Modulation of cytochrome P450 activity: implications for cancer therapy. In Lancet Oncol. Volume 6. England; 2005:780-789.

6. Blumberg B, Sabbagh W Jr, Juguilon H, Bolado J, van Meter CM Jr, Ong ES, Evans RM: SXR, a novel steroid and xenobiotic-sensing nuclear receptor. Genes Dev 1998, 12:3195-3205.

7. Goodwin B, Hodgson E, Liddle C: The orphan human pregnane $X$ receptor mediates the transcriptional activation of CYP3A4 by rifampicin through a distal enhancer module. Mol Pharmacol 1999, 56:1329-1339.

8. Kliewer SA, Moore JT, Wade L, Staudinger JL, Watson MA, Jones SA, McKee DD, Oliver BB, Willson TM, Zetterstrom RH, Perlmann T, Lehmann JM: An orphan nuclear receptor activated by pregnanes defines a novel steroid signaling pathway. In Cell. Volume 92. United States; 1998:73-82.

9. Lehmann JM, McKee DD, Watson MA, Willson TM, Moore JT, Kliewer SA: The human orphan nuclear receptor PXR is activated by compounds that regulate CYP3A4 gene expression and cause drug interactions. $J$ Clin Invest 1998, 102:1016-1023.

10. Lemaire $G$, de Sousa G, Rahmani R: A PXR reporter gene assay in a stable cell culture system: CYP3A4 and CYP2B6 induction by pesticides. In Biochem Pharmacol. Volume 68. England; 2004:2347-2358.

11. Chen Y, Ferguson SS, Negishi M, Goldstein JA: Identification of constitutive androstane receptor and glucocorticoid receptor binding sites in the CYP2C19 promoter. In Mol Pharmacol. Volume 64. United States; 2003:316-324.

12. Chen Y, Ferguson SS, Negishi M, Goldstein JA: Induction of human CYP2C9 by rifampicin, hyperforin, and phenobarbital is mediated by the pregnane X receptor. In J Pharmacol Exp Ther. Volume 308. United States; 2004:495-501.

13. Ferguson SS, Chen Y, LeCluyse EL, Negishi M, Goldstein JA: Human CYP2C8 is transcriptionally regulated by the nuclear receptors constitutive 
androstane receptor, pregnane $\mathrm{X}$ receptor, glucocorticoid receptor, and hepatic nuclear factor 4 alpha. In Mol Pharmacol. Volume 68. United States; 2005:747-757.

14. Gerbal-Chaloin S, Pascussi JM, Pichard-Garcia L, Daujat M, Waechter F, Fabre JM, Carrere N, Maurel P: Induction of CYP2C genes in human hepatocytes in primary culture. Drug Metab Dispos 2001, 29:242-251.

15. Goodwin B, Moore LB, Stoltz CM, McKee DD, Kliewer SA: Regulation of the human CYP2B6 gene by the nuclear pregnane $X$ receptor. $\mathrm{Mol}$ Pharmacol 2001, 60:427-431.

16. Xie W, Yeuh MF, Radominska-Pandya A, Saini SP, Negishi Y, Bottroff BS, Cabrera GY, Tukey RH, Evans RM: Control of steroid, heme, and carcinogen metabolism by nuclear pregnane $\mathrm{X}$ receptor and constitutive androstane receptor. In Proc Natl Acad Sci USA. Volume 100. United States; 2003:4150-4155.

17. Frank C, Makkonen H, Dunlop TW, Matilainen M, Vaisanen S, Carlberg C: Identification of pregnane $\mathrm{X}$ receptor binding sites in the regulatory regions of genes involved in bile acid homeostasis. In J Mol Biol. Volume 346. England; 2005:505-519.

18. Geick A, Eichelbaum M, Burk O: Nuclear receptor response elements mediate induction of intestinal MDR1 by rifampin. In J Biol Chem. Volume 276. United States; 2001:14581-14587.

19. Aggarwal S, Chu E: Current therapies for advanced colorectal cancer. Oncology (Williston Park) 2005, 19:589-595.

20. Humerickhouse R, Lohrbach K, Li L, Bosron WF, Dolan ME: Characterization of CPT-11 hydrolysis by human liver carboxylesterase isoforms hCE-1 and hCE-2. Cancer Res 2000, 60:1189-1192.

21. Pommier Y: Topoisomerase I inhibitors: camptothecins and beyond. In Nat Rev Cancer. Volume 6. England; 2006:789-802.

22. Santos A, Zanetta S, Cresteil T, Deroussent A, Pein F, Raymond E, Vernillet L, Risse ML, Boige V, Gouyette A, Vassal G: Metabolism of irinotecan (CPT-11) by CYP3A4 and CYP3A5 in humans. Clin Cancer Res 2000, 6:2012-2020.

23. Gagne JF, Montminy V, Belanger P, Journault K, Gaucher G, Guillemette C: Common human UGT1A polymorphisms and the altered metabolism of irinotecan active metabolite 7-ethyl-10-hydroxycamptothecin (SN-38). Mol Pharmacol 2002, 62:608-617.

24. Chen ZS, Furukawa T, Sumizawa T, Ono K, Ueda K, Seto K, Akiyama SI: ATPDependent efflux of CPT-11 and SN-38 by the multidrug resistance protein (MRP) and its inhibition by PAK-104P. Mol Pharmacol 1999, 55:921-928.

25. Chu $X Y$, Kato $Y$, Sugiyama $Y$ : Multiplicity of biliary excretion mechanisms for irinotecan, CPT-11, and its metabolites in rats. Cancer Res 1997, 57:1934-1938.

26. Iyer L, Ramirez J, Shepard DR, Bingham CM, Hossfeld DK, Ratain MJ, Mayer U: Biliary transport of irinotecan and metabolites in normal and Pglycoprotein-deficient mice. Cancer Chemother Pharmacol 2002, 49:336-341.

27. Kawabata S, Oka M, Shiozawa K, Tsukamoto K, Nakatomi K, Soda H, Fukuda M, Ikegami Y, Sugahara K, Yamada Y, Kamihira S, Doyle LA, Ross DD, Kohno S: Breast cancer resistance protein directly confers SN-38 resistance of lung cancer cells. In Biochem Biophys Res Commun. Volume 280. United States; 2001:1216-1223.

28. Nakatomi K, Yoshikawa M, Oka M, Ikegami Y, Hayasaka S, Sano K, Shiozawa K, Kawabata S, Soda H, Ishikawa T, Tanabe S, Kohno S: Transport of 7-ethyl-10-hydroxycamptothecin (SN-38) by breast cancer resistance protein ABCG2 in human lung cancer cells. In Biochem Biophys Res Commun. Volume 288. United States, Academic Press; 2001:827-832.

29. Mangelsdorf DJ, Thummel C, Beato M, Herrlich P, Schutz G, Umesono K, Blumberg B, Kastner P, Mark M, Chambon P, Evans RM: The nuclear receptor superfamily: the second decade. In Cell. Volume 83. United States; 1995:835-839.

30. Xie W, Barwick JL, Simon CM, Pierce AM, Safe S, Blumberg B, Guzelian PS, Evans RM: Reciprocal activation of xenobiotic response genes by nuclear receptors SXR/PXR and CAR. Genes Dev 2000, 14:3014-3023.

31. Zhou C, Verma S, Blumberg B: The steroid and xenobiotic receptor (SXR), beyond xenobiotic metabolism. Nucl Recept Signal 2009, 7:e001.

32. Masuyama H, Suwaki N, Tateishi Y, Nakatsukasa H, Segawa T, Hiramatsu Y: The pregnane $X$ receptor regulates gene expression in a ligand- and promoter-selective fashion. In Mol Endocrinol. Volume 19. United States; 2005:1170-1180.

33. Zhou C, Tabb MM, Sadatrafiei A, Grun F, Blumberg B: Tocotrienols activate the steroid and xenobiotic receptor, SXR, and selectively regulate expression of its target genes. In Drug Metab Dispos. Volume 32. United States; 2004:1075-1082.

34. Watkins RE, Wisely GB, Moore LB, Collins JL, Lambert MH, Williams SP, Willson TM, Kliewer SA, Redinbo MR: The human nuclear xenobiotic receptor PXR: structural determinants of directed promiscuity. In Science. Volume 292. United States; 2001:2329-2333.

35. Synold TW, Dussault I, Forman BM: The orphan nuclear receptor SXR coordinately regulates drug metabolism and efflux. In Nat Med. Volume 7. United States: 2001:584-590.

36. Xu G, Zhang W, Ma MK, McLeod HL: Human carboxylesterase 2 is commonly expressed in tumor tissue and is correlated with activation of irinotecan. Clin Cancer Res 2002, 8:2605-2611.

37. Zhou J, Liu M, Zhai $Y$, Xie W: The antiapoptotic role of pregnane $X$ receptor in human colon cancer cells. In Mol Endocrinol. Volume 22. United States; 2008:868-880.

38. Zucchini N, de Sousa G, Bailly-Maitre B, Gugenheim J, Bars R, Lemaire G, Rahmani R: Regulation of $\mathrm{BCl}-2$ and $\mathrm{BCl}-\mathrm{xL}$ anti-apoptotic protein expression by nuclear receptor PXR in primary cultures of human and rat hepatocytes. In Biochim Biophys Acta. Volume 1745. Netherlands; 2005:48-58.

39. Verma S, Tabb MM, Blumberg B: Activation of the steroid and xenobiotic receptor, SXR, induces apoptosis in breast cancer cells. In BMC Cancer. Volume 9. England; 2009:3.

40. Gong H, Singh SV, Singh SP, Mu Y, Lee JH, Saini SP, Toma D, Ren S, Kagan VE, Day BW, Zimniak $P$, Xie W: Orphan nuclear receptor pregnane $X$ receptor sensitizes oxidative stress responses in transgenic mice and cancerous cells. In Mol Endocrinol. Volume 20. United States; 2006:279-290.

41. Desai PB, Nallani SC, Sane RS, Moore LB, Goodwin BJ, Buckley DJ, Buckley AR: Induction of cytochrome P450 3A4 in primary human hepatocytes and activation of the human pregnane $X$ receptor by tamoxifen and 4-hydroxytamoxifen. Drug Metab Dispos 2002, 30:608-612.

42. Mensah-Osman EJ, Thomas DG, Tabb MM, Larios JM, Hughes DP Giordano TJ, Lizyness ML, Rae JM, Blumberg B, Hollenberg PF, Baker LH: Expression levels and activation of a PXR variant are directly related to drug resistance in osteosarcoma cell lines. Cancer 2007, 109:957-965.

43. Takami N, Sakamoto H, Yamamoto T: Steroid and xenobiotic receptor (SXR) is a key system for the acquisition of cisplatin resistance in endometrial cancer cells. J Int Med Res 2003, 31:59-68.

44. Masuyama H, Nakatsukasa H, Takamoto N, Hiramatsu Y: Down-regulation of pregnane $X$ receptor contributes to cell growth inhibition and apoptosis by anticancer agents in endometrial cancer cells. In Mol Pharmacol. Volume 72. United States; 2007:1045-1053.

45. Chen $Y$, Tang $Y$, Wang MT, Zeng $S$, Nie D: Human pregnane $X$ receptor and resistance to chemotherapy in prostate cancer. In Cancer Res. Volume 67. United States; 2007:10361-10367.

46. Jiang H, Chen K, He J, Pan F, Li J, Chen J, Chen W, Liang H: Association of pregnane $\mathrm{X}$ receptor with multidrug resistance-related protein 3 and its role in human colon cancer chemoresistance. J Gastrointest Surg 2009, 13:1831-1838.

47. Dussault I, Lin M, Hollister K, Wang EH, Synold TW, Forman BM: Peptide mimetic HIV protease inhibitors are ligands for the orphan receptor SXR In J Biol Chem. Volume 276. United States; 2001:33309-33312.

48. Moore LB, Goodwin B, Jones SA, Wisely GB, Serabjit-Singh CJ, Willson TM, Collins JL, Kliewer SA: St. John's wort induces hepatic drug metabolism through activation of the pregnane $X$ receptor. In Proc Natl Acad Sci USA. Volume 97. United States; 2000:7500-7502.

49. Wentworth JM, Agostini M, Love J, Schwabe JW, Chatterjee VK: St John's wort, a herbal antidepressant, activates the steroid $\mathrm{X}$ receptor. In $J$ Endocrinol. Volume 166. England; 2000:R11-16.

50. Friedman HS, Petros WP, Friedman AH, Schaaf LJ, Kerby T, Lawyer J, Parry M, Houghton PJ, Lovell S, Rasheed K, Cloughsey T, Stewart ES, Colvin OM, Provenzale JM, McLendon RE, Bigner DD, Cokgor I, Haglund M, Rich J, Ashley D, Malczyn J, Elfring GL, Miller LL: Irinotecan therapy in adults with recurrent or progressive malignant glioma. J Clin Oncol 1999, 17:1516-1525

51. Prados MD, Yung WK, Jaeckle KA, Robins HI, Mehta MP, Fine HA, Wen PY, Cloughesy TF, Chang SM, Nicholas MK, Schiff D, Greenberg HS, Junck L, Fink KL, Hess KR, Kuhn J, North American Brain Tumor Consortium study: Phase 1 trial of irinotecan (CPT-11) in patients with recurrent malignant glioma: a North American Brain Tumor Consortium study. Neuro Oncol 2004, 6:44-54. 
52. Chomczynski P, Sacchi N: Single-step method of RNA isolation by acid guanidinium thiocyanate-phenol-chloroform extraction. In Anal Biochem. Volume 162. United States; 1987:156-159.

53. Fink L, Seeger W, Ermert L, Hanze J, Stahl U, Grimminger F, Kummer W, Bohle RM: Real-time quantitative RT-PCR after laser-assisted cell picking Nat Med 1998, 4:1329-1333.

54. Lamba V, Yasuda K, Lamba JK, Assem M, Davila J, Strom S, Schuetz EG: PXR (NR112): splice variants in human tissues, including brain, and identification of neurosteroids and nicotine as PXR activators. In Toxicol Appl Pharmacol. Volume 199. United States; 2004:251-265.

55. Skehan P, Storeng R, Scudiero D, Monks A, McMahon J, Vistica D, Warren IT, Bokesch H, Kenney S, Boyd MR: New colorimetric cytotoxicity assay for anticancer-drug screening. J Natl Cancer Inst 1990, 82:1107-1112.

doi:10.1186/1476-4598-10-80

Cite this article as: Basseville et al:: Irinotecan induces steroid and xenobiotic receptor (SXR) signaling to detoxification pathway in colon cancer cells. Molecular Cancer 2011 10:80.

\section{Submit your next manuscript to BioMed Central} and take full advantage of:

- Convenient online submission

- Thorough peer review

- No space constraints or color figure charges

- Immediate publication on acceptance

- Inclusion in PubMed, CAS, Scopus and Google Scholar

- Research which is freely available for redistribution

Submit your manuscript at www.biomedcentral.com/submit 